\title{
Elemental indicators of natural and anthropogenic aerosol inputs to Law Dome, Antarctica
}

\author{
Paul VALLELONGA, ${ }^{1,2}$ Carlo BARBANTE, ${ }^{2,3}$ Giulio COZZI, ${ }^{2}$ Vania GASPARI, ${ }^{2}$ \\ Jean-Pierre CANDELONE, ${ }^{1}$ Katja VAN DE VELDE, ${ }^{1}$ Vin I. MORGAN, ${ }^{4}$ \\ Kevin J. R. ROSMAN, ${ }^{1}$ Claude F. BOUTRON, ${ }^{5}$ Paolo CESCON ${ }^{2,3}$ \\ ${ }^{1}$ Department of Applied Physics, Curtin University of Technology, Box U 1987, Perth 6845, Australia \\ E-mail: p.vallelonga@curtin.edu.au \\ ${ }^{2}$ Department of Environmental Sciences, University of Venice, Dorsoduro 2137, I-30123 Venice, Italy \\ ${ }^{3}$ Institute for the Dynamics of Environmental Processes (CNR), University of Venice, Dorsoduro 2137, I-30123 Venice, Italy \\ ${ }^{4}$ Antarctic CRC and Australian Antarctic Division, Box 252-80, Hobart, Tasmania 7001, Australia \\ ${ }^{5}$ Laboratoire de Glaciologie et Géophysique de I'Environnement du CNRS, 54 rue Molière, Domaine Universitaire, BP 96, \\ 38402 Saint-Martin-d'Hères Cedex, France
}

\begin{abstract}
A selection of elements $(\mathrm{Bi}, \mathrm{Ca}, \mathrm{Cd}, \mathrm{Co}, \mathrm{Cu}, \mathrm{Mn}, \mathrm{Na}, \mathrm{Sr}, \mathrm{U}, \mathrm{V}, \mathrm{Zn}$ ) were measured by highresolution inductively coupled plasma sector-field mass spectrometry in firn- and ice-core samples from Law Dome, Antarctica, corresponding to the period 4500 BC to AD 1989. Concentrations of rock dust and sea salts were calculated for each sample and then used to determine concentrations of each element originating from crustal and marine aerosol emissions, respectively. Where calculated contributions from crustal and marine aerosol sources failed to account for the total measured concentration of an element, the remainder was apportioned to volcanic and/or anthropogenic sources and defined as an enrichment. On this basis, it was determined that $\mathrm{Bi}$ and $\mathrm{Cd}$ concentrations in Law Dome ice are overwhelmingly influenced by volcanic emissions (enrichments 150-250x crustal and marine inputs); $\mathrm{Co}, \mathrm{Cu}, \mathrm{Pb}$ and $\mathrm{Zn}$ concentrations in Law Dome ice are largely influenced by volcanic emissions (enrichments 16-36x crustal and marine inputs); and $\mathrm{Mn}, \mathrm{Sr}, \mathrm{U}$ and $\mathrm{V}$ concentrations in Law Dome ice are minimally influenced by volcanic emissions (enrichments 1.5-4x crustal and marine inputs). During the 20th century, enrichments of $\mathrm{Pb}$ and $\mathrm{Cu}$ concentrations were observed to be greater than in earlier centuries, consistent with increasing anthropogenic emissions of $\mathrm{Pb}$ and $\mathrm{Cu}$ in the Southern Hemisphere over that period.
\end{abstract}

\section{INTRODUCTION}

Polar ice-core records enable hemispheric trends of atmospheric aerosol loading to be determined and have been used to compare changes in the composition of aerosols in the atmosphere with various large-scale forcing events such as glacial-interglacial transitions (e.g. Basile and others, 1997; Petit and others, 1999) and, in more recent times, anthropogenic activities (Rosman and others, 1997; Wolff and others, 1999; Planchon and others, 2002). The study of elemental concentrations in polar archives also enables various anthropogenic aerosol-emission processes (e.g. leaded gasoline, coal and oil combustion; ore mining and metal production) to be evaluated and has resulted in the characterization of long-term trends in the development of industrial activity in the Northern (Rosman and others, 1994b; Barbante and others, 2003) and Southern (Vallelonga and others, 2002b; Planchon and others, 2003) Hemispheres.

Despite such progress, attention has recently been directed toward discrepancies and systematic errors in earlier attempts to constrain the natural sources of some elements deposited on the Antarctic ice sheet (Matsumoto and Hinkley, 2001). Earlier studies (e.g. Boutron and others, 1987; Rosman and others, 1994a; Hong and others, 1998) had attributed the presence of heavy metals in the Antarctic ice sheet to a combination of crustal (wind-blown rock and dust), marine (sea-salt spray and/or emissions from marine biogenic activity) and volcanogenic aerosols but had used diverse methods for quantifying inputs from these sources. In some studies, corrections such as 'emission factors' have been incorporated to account for poorly documented phenomena, such as the enrichment of heavy metals during the production of sea-salt spray (Weisel and others, 1984; Nriagu, 1989; Dick, 1991). Because this phenomenon has not been thoroughly evaluated, the 'emission factors' applied in past studies have sometimes been grossly overestimated: values as great as 10000 for $\mathrm{Cd}$ and 20000 for Zn (Hong, 1998) have been used to describe the enrichment of these elements relative to sea-water concentrations. Recent studies have employed smaller emission factors as it becomes apparent that such large corrections are unnecessary (Planchon and others, 2002).

Overall, there remain great discrepancies between the relative contributions of metals to the Antarctic ice sheet from different natural emission sources, due to the diverse methods and corrections applied by different investigators over time. Evaluations of aerosol emissions from crustal and marine sources have been treated more accurately than those from volcanic sources, since the composition of the Earth's crust and seas has been well studied while our knowledge of the composition of volcanic exhalations extends to only 13 elements (Hinkley and others, 1999). Nonetheless, there exists new evidence to suggest that quiescent volcanism may account for the majority of some metals deposited on the Antarctic ice sheet (Matsumoto and Hinkley, 2001). 
Law Dome, a coastal high-snow-accumulation site located in East Antarctica, has been the subject of interest for the production of high-resolution millennia-long records of climatic and atmospheric change from ice-core records (Morgan and others, 1997). Concentrations of trace metals $(\mathrm{Pb}, \mathrm{Cd}, \mathrm{Cu}, \mathrm{Zn})$ have been reported for some recent ice strata (Hong and others, 1998), but some of these samples have been shown to be subject to contamination from the drilling procedure (Rosman and others, 1998). More recently a 500 year history of $\mathrm{Pb}$ and $\mathrm{Ba}$ concentrations and $\mathrm{Pb}$ isotopes has been published, indicating the influence of anthropogenic aerosols at Law Dome since approximately AD 1890 (Vallelonga and others, 2002b). The proportions of heavy metals originating from natural aerosol emission sources have been little studied, although the changes in $\mathrm{Pb}$, $\mathrm{Ba}$ and $\mathrm{Bi}$ deposition during the AD 1815 Tambora (Indonesia) volcanic eruption have been reported (Vallelonga and others, 2003). The seasonal deposition characteristics of major ions at the site (Curran and others, 1998) and a 700 year record of volcanic activity determined from nonsea-salt $\mathrm{SO}_{4}{ }^{2-}\left(\mathrm{nssSO}_{4}{ }^{2-}\right)$ concentrations are also available (Palmer and others, 2001).

Here, we make use of high-resolution inductively coupled plasma sector-field mass spectrometry (ICP-SFMS) to analyze a suite of major, minor and trace elements in Law Dome samples that have previously been studied for $\mathrm{Pb}$ and Ba concentrations and $\mathrm{Pb}$ isotopes by Thermal Ionization Mass Spectrometry (TIMS). These data are used to complement the existing record of anthropogenic aerosols deposition at Law Dome by providing a more thorough characterization of the natural sources of a variety of elements deposited at the site.

\section{METHODS}

\section{Ice cores, sampling and decontamination}

Details of the Law Dome ice cores selected, their decontamination and sampling have been described previously (Vallelonga and others, 2002a), so only a summary is provided here. Samples were obtained from five different ice cores, four located near the Law Dome summit $\left(66^{\circ} 46^{\prime} \mathrm{S}\right.$, $112^{\circ} 48^{\prime} \mathrm{E}$; $1390 \mathrm{~m}$ a.s.I.; accumulation rate $>600 \mathrm{~kg} \mathrm{~m}^{-2} \mathrm{a}^{-1}$, mean annual temperature $-21.8^{\circ} \mathrm{C}$, approximate distance from coast $80 \mathrm{~km}$ ) and one located $20 \mathrm{~km}$ to the west (DSSW20k; accumulation rate $160 \mathrm{~kg} \mathrm{~m}^{-2} \mathrm{a}^{-1}$ ). The ice cores were dated by counting of annual $\delta^{18} \mathrm{O}$ layers in the ice record and correlation with the accurately dated DSS main core (Palmer and others, 2001), while the DSS-W20k core was dated using snow densification and ice-flow modelling, trapped-gas measurements and identification of the nssSO $_{4}{ }^{2-}$ signal corresponding to the AD 1815 Tambora eruption (Vallelonga and others, 2003).

Ice-core sections as long as $70 \mathrm{~cm}$ were decontaminated on an acid-cleaned all-plastic lathe located in a High Efficiency Particle Air- (HEPA-)filtered laminar-flow bench using a mechanical-chiselling technique (Candelone and others, 1994). This technique of sequentially removing concentric layers of ice was followed in order to remove surface contamination originating from the drilling and longterm storage of the ice cores, leaving the central section of the core (the 'inner core') pristine and free from contamination. Decontamination personnel wore lint-free coveralls and plastic gloves, and all equipment used was cleaned in heated baths of dilute nitric acid produced from ultra-pure water and nitric acid which had been purified by sub-boiling distillation in a quartz still. The chiselled samples were melted and aliquotted in a clean laboratory supplied with HEPA-filtered air, where they were transferred unacidified into acid-cleaned low-density polyethylene (LDPE) bottles. The samples were then frozen and transported to the University of Venice, Italy, for ICP-SFMS analyses. Blanks resulting from the decontamination and sample storage procedures have been evaluated for $\mathrm{Ba}$ and $\mathrm{Pb}$ (Vallelonga and others, 2002a) and were found to be negligible $\left(13 \mathrm{fg} \mathrm{Pb} \mathrm{g}^{-1}, 43 \mathrm{fg} \mathrm{Ba} \mathrm{g}^{-1}\right)$.

\section{ICP-SFMS analysis}

A ThermoFinnigan Element2 ICP-SFMS instrument was used to measure $\mathrm{Bi}, \mathrm{Ca}, \mathrm{Cd}, \mathrm{Co}, \mathrm{Cu}, \mathrm{Mn}, \mathrm{Na}, \mathrm{Sr}, \mathrm{U}, \mathrm{V}$ and $\mathrm{Zn}$. The operating procedures and measurement parameters used for the analyses have been reported previously by Planchon and others (2001). A PFA Teflon nebulizer (Elemental Scientific, Omaha, NE, USA) with a sample consumption rate of approximately $100 \mu \mathrm{Lmin}^{-1}$ was used for all samples. Detection limits varied between $0.003 \mathrm{pgg}^{-1}$ for $U$ and $0.6 \mathrm{pg} \mathrm{g}^{-1}$ for Mn. Typical measurement precisions (given in terms of relative standard deviations) were found to vary from $9 \%$ for $\mathrm{Sr}$ to $43 \%$ for $\mathrm{U}$.

Although $\mathrm{Ba}$ and $\mathrm{Pb}$ were also analyzed by ICP-SFMS, Ba and $\mathrm{Pb}$ concentrations determined by isotope dilution TIMS (Vallelonga and others, 2002b) - in the same samples have been included here to indicate inputs from crustal rock and soil dust and from some anthropogenic sources, respectively. Good agreement was found between the concentrations of $\mathrm{Pb}$ measured in identical samples using TIMS and ICP-SFMS; however, for $\mathrm{Ba}$ it was found that average concentrations measured by ICP-SFMS were only $40 \%$ of those measured by TIMS. The lower concentrations of Ba observed by ICP-SFMS are attributed to the incomplete ionization of $\mathrm{Ba}$ in dust particles present in the ICP-SFMS plasma.

\section{RESULTS}

The results of ICP-SFMS analysis of 32 firn- and ice-core samples collected from Law Dome ice-core sections are shown in Table 1. Included in the table are $\mathrm{Ba}$ and $\mathrm{Pb}$ concentrations determined by TIMS in the same samples, as reported by Vallelonga and others (2002b). From the evaluation of $\mathrm{Pb}$ isotopes given therein, it was determined that the influence of anthropogenic Pb emissions is apparent at Law Dome from AD 1898. It is assumed that only minor quantities of heavy metals were emitted by anthropogenic activities in the Southern Hemisphere prior to AD 1898, thus allowing the proportions of natural sources of heavy-metals emissions to be evaluated from data corresponding to the pre-AD 1898 period. Elemental concentrations reported here are generally in agreement with those reported by Wolff and others (1999) and Planchon and others (2002) for Coats Land snow blocks and firn/ice cores, respectively. Concentrations of $\mathrm{Bi}, \mathrm{Cd}$ and $\mathrm{Co}$ determined here are moderately higher than those reported for Coats Land, which may be due to different mixtures of aerosols emitted from various natural sources being archived at each site.

\section{Quality of the data: decontamination profiles}

Profiles of the decontaminated core layers were analyzed for several samples to evaluate the reliability of the measured 
Table 1. Results of ICP-SFMS analysis of 32 firn- and ice-core sections collected from Law Dome, and calculated concentrations of rock dust and sea salts. '<d.I.' indicates that the measured concentration in the sample was below the detection limit. Calculation of rock-dust and seasalts concentrations is discussed in the text

\begin{tabular}{|c|c|c|c|c|c|c|c|c|c|c|c|c|c|c|c|c|}
\hline $\begin{array}{l}\text { Sample } \\
\text { code }\end{array}$ & Date & $\begin{array}{l}\mathrm{Ba}^{*} \\
\mathrm{pgg}^{-1}\end{array}$ & $\begin{array}{l}\mathrm{Bi} \\
\mathrm{pgg}^{-1}\end{array}$ & $\begin{array}{l}\mathrm{Ca} \\
\mathrm{ngg}^{-1}\end{array}$ & $\begin{array}{l}\mathrm{Cd} \\
\operatorname{pgg}^{-1}\end{array}$ & $\begin{array}{l}\text { Co } \\
\text { pg g }^{-1}\end{array}$ & $\begin{array}{l}\mathrm{Cu} \\
\mathrm{pg} \mathrm{g}^{-1}\end{array}$ & $\begin{array}{l}\mathrm{Mn} \\
\mathrm{pg} \mathrm{g}^{-1}\end{array}$ & $\begin{array}{l}\mathrm{Na} \\
\mathrm{ng} \mathrm{g}^{-1}\end{array}$ & $\begin{array}{l}\mathrm{Pb}^{*} \\
\mathrm{pg} \mathrm{g}^{-1}\end{array}$ & $\begin{array}{l}\mathrm{Sr} \\
\mathrm{pgg}^{-1}\end{array}$ & $\begin{array}{l}U \\
\operatorname{pgg}^{-1}\end{array}$ & $\begin{array}{l}\text { V } \\
\operatorname{pg~g}^{-1}\end{array}$ & $\begin{array}{l}\mathrm{Zn} \\
\mathrm{pgg}^{-1}\end{array}$ & $\begin{array}{l}\text { Rock } \\
\text { dust } \\
\operatorname{ngg}^{-1}\end{array}$ & $\begin{array}{l}\text { Sea } \\
\text { salts } \\
\mathrm{ngg}^{-1}\end{array}$ \\
\hline DSS 1129 & 4500 вС & 3.21 & 0.06 & 1.22 & 0.17 & 0.82 & - & 3.6 & 44 & 0.31 & 44.7 & 0.042 & 1.4 & 0.6 & 4.7 & 125 \\
\hline BHQ 260 & 4000 BС & - & 0.04 & 1.24 & 0.11 & $<$ d.I. & $<$ d.I. & 3.8 & 39 & - & 47.5 & 0.012 & $<$ d.I. & - & & 148 \\
\hline DSS 790 & AD 68 & 1.83 & 0.07 & 1.37 & 0.15 & 0.97 & 0.3 & 4.9 & 44 & 0.42 & 49.1 & 0.034 & 1.5 & 1.7 & 2.7 & 152 \\
\hline DSS 257 & AD 1530 & 0.68 & 0.05 & 1.45 & 0.28 & 1.66 & $<$ d.I. & 3.3 & 42 & 0.30 & 44.0 & 0.011 & 0.3 & 3.3 & 0.9 & 169 \\
\hline DSS 218 & AD 1605 & 1.30 & 0.05 & 1.91 & 0.08 & 0.87 & $<$ d.I. & 1.9 & 58 & 0.33 & 68.7 & 0.016 & 1.1 & 1.7 & 1.8 & 220 \\
\hline BHD 132 & AD 1650 & 1.37 & 0.03 & 1.65 & 0.13 & 0.79 & 1.3 & 1.7 & 52 & 0.48 & 57.6 & 0.027 & 1.1 & 0.9 & 1.9 & 188 \\
\hline DSS-W20k 70 & AD 1692 & 1.40 & 0.05 & 1.04 & 0.17 & 0.86 & 0.2 & 3.4 & 37 & 0.33 & 34.6 & 0.014 & 1.2 & 1.6 & 2.0 & 115 \\
\hline DSS-W20k 62 & AD 1729 & 0.75 & 0.18 & 1.62 & 0.29 & 3.25 & $<0.6$ & 5.8 & 45 & 0.27 & 59.9 & 0.023 & 1.9 & - & 1.0 & 189 \\
\hline DSS-W20k 55 & AD 1767 & 1.81 & 0.07 & 2.68 & 0.18 & 1.09 & 1.1 & 4.7 & 79 & 0.36 & 99.5 & 0.034 & 1.5 & 2.3 & 2.5 & 308 \\
\hline DSS-W20k 50 & AD 1790 & 1.50 & 0.06 & 2.07 & 0.30 & 1.59 & 0.8 & 4.3 & 58 & 0.47 & 75.1 & 0.020 & 0.1 & 2.9 & 2.1 & 237 \\
\hline DSS-W20k 46 & AD 1807 & 1.98 & 0.07 & 2.74 & 0.08 & 0.89 & 1.2 & 2.9 & 75 & 0.36 & 108.3 & 0.033 & 1.5 & 0.6 & 2.8 & 314 \\
\hline DSS-W20k 41 & AD 1831 & 0.90 & 0.05 & 3.96 & 0.09 & 1.38 & 1.4 & 2.4 & 48 & 0.45 & 121.7 & 0.035 & 1.5 & 1.9 & 1.1 & 467 \\
\hline DSS99 103 & AD 1852 & 1.02 & 0.03 & 1.56 & 0.18 & 1.24 & $<$ d.I. & 3.4 & 45 & 0.28 & 49.0 & 0.016 & 0.2 & $<1.5$ & 1.4 & 180 \\
\hline DSS-W20k 35 & AD 1858 & 1.02 & 0.10 & 2.22 & - & 1.93 & 1.2 & 6.0 & 61 & 0.21 & 79.1 & 0.027 & 0.3 & - & 1.4 & 258 \\
\hline DSS99 95 & AD 1860 & 0.90 & 0.01 & 1.26 & 0.15 & $<$ d.I. & $<$ d.I. & 2.0 & 39 & 0.32 & 49.0 & 0.009 & $<$ d.I. & $<0.8$ & 1.3 & 145 \\
\hline DSS99 84 & AD 1877 & 0.67 & 0.09 & 1.04 & 0.10 & 0.68 & 0.5 & 1.7 & 38 & 0.41 & 39.1 & 0.009 & 1.3 & 1.0 & 0.9 & 120 \\
\hline DSS99 79 & AD 1884 & 1.10 & 0.05 & 1.13 & 0.19 & 0.81 & $<$ d.I. & 1.8 & 42 & 0.45 & 38.3 & 0.016 & 1.0 & 0.6 & 1.6 & 128 \\
\hline DSS99 68 & AD 1898 & 1.49 & 0.04 & 1.68 & - & 0.65 & 3.7 & 2.4 & 53 & 1.42 & 68.2 & 0.025 & 0.4 & - & 2.1 & 191 \\
\hline DSS99 60 & AD 1908 & 1.72 & 0.03 & 2.37 & 0.13 & <d.I. & 0.3 & 2.2 & 72 & 1.69 & 91.0 & 0.031 & 0.3 & 0.5 & 2.4 & 272 \\
\hline DSS99 40 & AD 1932 & 6.67 & 0.04 & 1.28 & 0.08 & 1.41 & 0.6 & 7.3 & 37 & 1.10 & 37.8 & 0.086 & 1.7 & 4.5 & 10.0 & 109 \\
\hline DSS-W20k 18 & AD 1933 & 2.16 & 0.05 & 2.34 & - & $<$ d.I. & - & 3.8 & 71 & 1.72 & 91.1 & 0.025 & 0.4 & - & 3.1 & 265 \\
\hline DSS99 36 & AD 1939 & 1.08 & 0.04 & 1.42 & 0.13 & 1.26 & 1.5 & 9.8 & 47 & 0.79 & 54.8 & - & 1.0 & 4.0 & 1.5 & 162 \\
\hline DSS-W20k 16 & AD 1942 & 2.01 & 0.06 & 0.57 & $<$ d.I. & 1.40 & 0.6 & 4.9 & 26 & 0.59 & 30.5 & 0.015 & 1.5 & 2.1 & 3.0 & 55 \\
\hline DSS-W20k 15 & AD 1948 & 1.84 & 0.06 & 2.11 & 0.10 & 1.09 & 2.3 & 2.9 & 54 & 1.08 & 59.1 & 0.021 & 1.1 & - & 2.6 & 240 \\
\hline DSS-W20k 13 & AD 1956 & 3.75 & 0.04 & 1.47 & 0.21 & 1.32 & - & 3.5 & 47 & 1.27 & 52.3 & 0.020 & 0.8 & - & 5.5 & 151 \\
\hline DSS-W20k 12 & AD 1960 & 2.98 & 0.08 & 1.52 & 0.18 & 0.49 & 2.1 & 5.8 & 50 & 2.89 & 58.8 & 0.026 & 0.6 & 2.9 & 4.4 & 162 \\
\hline DSS-W20k 11 & AD 1964 & 3.47 & 0.04 & 2.85 & 0.23 & 0.58 & 2.6 & 7.3 & 82 & 1.51 & 106.5 & 0.042 & 0.7 & - & 5.0 & 318 \\
\hline DSS-W20k 10 & AD 1967 & 2.02 & 0.06 & 2.77 & 0.34 & 0.83 & 2.7 & 5.4 & 77 & 1.33 & 108.0 & 0.032 & 0.6 & - & 2.8 & 318 \\
\hline DSS-W20k 9 & AD 1971 & 2.42 & 0.03 & 4.40 & $<0.34$ & 0.62 & - & 5.9 & 53 & 2.46 & 132.5 & 0.030 & 0.8 & - & 3.3 & 510 \\
\hline DSS-W20k 7 & AD 1977 & 1.22 & 0.03 & 0.96 & 0.39 & 0.51 & 1.8 & 1.9 & 35 & 1.60 & 38.0 & 0.011 & 0.4 & $<15$ & 1.8 & 107 \\
\hline DSS-W2k 17 & AD 1983 & 1.72 & 0.05 & 0.54 & 0.40 & 1.03 & 4.8 & 2.4 & 24 & 0.88 & 20.4 & 0.023 & 1.0 & - & 2.6 & 53 \\
\hline DSS-W2k 9 & AD 1989 & 4.68 & 0.05 & 1.84 & 0.26 & 0.53 & 4.3 & 7.5 & 56 & 7.00 & 70.9 & 0.029 & 0.7 & - & 6.9 & 189 \\
\hline
\end{tabular}

*Lead and Ba concentrations determined by TIMS (Vallelonga and others, 2002b).

data and to investigate the presence of contamination on the innermost sections of the cores. For most elements $(\mathrm{Bi}, \mathrm{Ca}$, $\mathrm{Co}, \mathrm{Mn}, \mathrm{Na}, \mathrm{Sr}, \mathrm{U}, \mathrm{V})$, decontamination profiles displayed a plateau from the second or third layer of chiselled ice to the inner core, indicating that the external contamination had been successfully removed. For other elements $(\mathrm{Cd}, \mathrm{Cu}, \mathrm{Zn})$, only some of the decontaminations were successful, where an unsuccessful decontamination was indicated by a continuously decreasing concentration profile from the external section to the internal section of the core. This was found to occur most frequently in core samples corresponding to snow deposited since the 1940s, which were less dense (firn density approximately $500 \mathrm{~kg} \mathrm{~m}^{-3}$ ) than the deeper ice strata. The lesser density (hence greater porosity) of the uppermost core sections made these sections more susceptible to contamination transported by aerosols diffusing into the centre of the core. Where ice-core sections were not successfully decontaminated, the concentration found in the inner core sample has been reported as an upper limit.

\section{Evaluation of crustal and marine aerosol inputs}

Crustal and marine aerosol inputs of each of the elements studied have been evaluated based on the calculated concentrations of rock dust and sea salt present in each sample and the reported concentration of each element in crustal material and mean sea water. Concentrations of rock dust and sea salt were determined from $\mathrm{Ba} / \mathrm{Ca}$ ratios present in the samples compared to those $\mathrm{Ba} / \mathrm{Ca}$ ratios reported in crustal material (Taylor and McLennan, 1985) and sea water (Bowen, 1979). Ba/Ca ratios were used to differentiate rock dust from sea salts because of the great difference between the proportions of these two elements in rock dust $(0.018$; Taylor and McLennan, 1985) and sea salt $\left(3.2 \times 10^{-5}\right.$; Bowen, 1979). The following formula was used to calculate the proportion of sea salt in each sample:

$$
\text { Sea-salt proportion }=\frac{\frac{\mathrm{Ba}}{\mathrm{Ca}} \text { sample }-\frac{\mathrm{Ba}}{\mathrm{Ca}} \text { rock dust }}{\frac{\mathrm{Ba}}{\mathrm{Ca}} \text { sea salt }-\frac{\mathrm{Ba}}{\mathrm{Ca}} \text { rock dust }},
$$

while the proportion of rock dust in the sample was taken to be the remainder:

$$
\text { Rock-dust proportion }=1-\text { sea-salt proportion. }
$$

Once the proportions of rock dust and sea salt had been calculated for each sample, their respective quantities were calculated based on the reported abundance of $\mathrm{Ca}$ in crustal 
Table 2. Reported abundances of selected elements in upper continental crustal material (Taylor and McLennan, 1985) and sea water (Bowen, 1975). All values are given in $\mathrm{ng}^{-1}$

\begin{tabular}{lcc}
\hline \multirow{2}{*}{ Element } & \multicolumn{2}{c}{ Abundance } \\
\cline { 2 - 3 } & Earth's crust & Sea water \\
\hline $\mathrm{Ba}$ & $550 \times 10^{3}$ & 13 \\
$\mathrm{Bi}$ & 127 & 0.02 \\
$\mathrm{Ca}$ & $30 \times 10^{6}$ & $412 \times 10^{3}$ \\
$\mathrm{Cd}$ & 98 & 0.11 \\
$\mathrm{Co}$ & $10 \times 10^{3}$ & 0.02 \\
$\mathrm{Cu}$ & $25 \times 10^{3}$ & 0.25 \\
$\mathrm{Mn}$ & $600 \times 10^{3}$ & 0.2 \\
$\mathrm{Na}$ & $28.9 \times 10^{6}$ & $10.77 \times 10^{6}$ \\
$\mathrm{~Pb}$ & $20 \times 10^{3}$ & 0.03 \\
$\mathrm{Sr}$ & $350 \times 10^{3}$ & 7900 \\
$\mathrm{U}$ & $2.8 \times 10^{3}$ & 3.2 \\
$\mathrm{~V}$ & $60 \times 10^{3}$ & 2.5 \\
$\mathrm{Zn}$ & $71 \times 10^{3}$ & 4.9 \\
& & \\
\hline
\end{tabular}

material and sea water, using the following equations:

Rock-dust concentration

$$
=\text { rock-dust proportion } \times \frac{\text { Ca concentration in sample }}{\text { Ca crustal abundance }}
$$

Sea-salt concentration

$$
=\text { sea-salt proportion } \times \frac{\text { Ca concentration in sample }}{\text { Ca sea-water abundance }} \text {. }
$$

From these calculated concentrations of rock dust and sea salt in each sample, amounts of each of the studied elements were determined by multiplying this concentration with the reported abundance of these elements in crustal material (Taylor and McLennan, 1985) and sea water (Bowen, 1979), which are shown in Table 2. In calculating the concentration of each element present in the samples from sea-salt inputs, the reported sea-water abundance of the element was divided by 0.035 to account for salinity as shown:

Element concentration in sample from marine aerosols

$$
\begin{gathered}
=\text { Sea-salt concentration calculated in sample } \\
\times \frac{\text { Element abundance in sea-water }}{0.035} .
\end{gathered}
$$

No 'emission factor' correction was applied when calculating the amounts of sea-salt-derived elements, on the basis that the phenomenon of sea-salt spray enrichment has not been studied thoroughly enough. The results presented here suggest that the use of such 'emission factors' may be unnecessary for determining marine aerosol emissions of most of the elements considered.

Marine aerosols account for most of the $\mathrm{Ba}$ and $\mathrm{Ca}$ deposited in Law Dome ice. Sea salts were found to be the origin of approximately 98\% (average concentration $205 \mathrm{ng} \mathrm{g}^{-1}$ ) of $\mathrm{Ba}$ and $\mathrm{Ca}$ found in the samples, while rock dust accounted for only $2 \%\left(2.8 \mathrm{ng} \mathrm{g}^{-1}\right)$ of these elements. These results were independently tested by calculating seasalt and rock-dust concentrations in the samples directly from measured $\mathrm{Na}$ and $\mathrm{Ba}$ concentrations, which were respectively divided by the abundances of $\mathrm{Na}$ and $\mathrm{Ba}$ in sea water and upper crustal material shown in Table 2. These calculations indicated that average rock-dust concentrations at Law Dome were $3.6 \mathrm{ngg}^{-1}$, while average sea-salt concentrations were $230 \mathrm{ng} \mathrm{g}^{-1}$, both in good agreement with the results determined from $\mathrm{Ba} / \mathrm{Ca}$ ratios. The high correlation observed between concentrations of $\mathrm{Ca}, \mathrm{Na}$ and $\mathrm{Sr}$ (Ca-Na correlation: $r^{2}=0.96$; $\mathrm{Ca}-\mathrm{Sr}$ correlation: $\left.r^{2}=0.93\right)$ supports our finding that marine emissions are the dominant source of aerosols deposited at Law Dome.

While there was no apparent trend in sea-salt concentrations, rock-dust concentrations increased from $1.9 \mathrm{ng} \mathrm{g}^{-1}$ between $6500 \mathrm{BP}$ and AD 1884, to $3.8 \mathrm{ng} \mathrm{g}^{-1}$ between AD 1898 and 1989. Vallelonga and others (2002b) suggested that the elevated dust concentrations observed at Law Dome during the 1930s and from 1956 to 1964 could result from changes to vegetation cover possibly caused by climate change. Decreased enrichments (beyond calculated sea-salt and rock-dust inputs) were observed for $\mathrm{Bi}, \mathrm{Co}, \mathrm{Mn}, \mathrm{U}$ and $\mathrm{V}$ during the 20th century compared to pre-industrial levels and are consistent with a recent increase in dust levels.

On average, $\mathrm{Sr}$ was enriched 1.4 times above concentrations expected from rock-dust and sea-salt inputs, while the average enrichment of $\mathrm{Mn}, \mathrm{U}$ and $\mathrm{V}$ was 3-4 times above concentrations expected from rock dust and sea salts. Our interpretation of these elemental enrichments above calculated sea-salt and rock-dust concentrations is based on the comments of Duce and others (1975) who suggested '[enrichment] variations from unity up to an order of magnitude may still indicate a crustal material source for the elements', so only enrichments greater than an order of magnitude above crustal and marine aerosol inputs have been considered as definitely indicative of the influence of other emission sources. As the amounts of $\mathrm{Mn}, \mathrm{Sr}, \mathrm{U}$ and $\mathrm{V}$ present in Law Dome ice were only moderately greater than estimated proportions of rock dust and sea salt, rock dust was considered the dominant source of $\mathrm{Mn}, \mathrm{U}$ and $\mathrm{V}$, while sea salt was usually found to account for $97 \%$ of measured Sr concentrations.

\section{Evaluation of volcanic and anthropogenic aerosol inputs}

Contributions of elements originating from volcanogenic and anthropogenic aerosol emissions were evaluated by consideration of the enrichment of each element beyond concentrations that can be accounted for by rock-dust and sea-salt inputs. Where the enrichment of an element was observed to be approximately constant in all of the samples, volcanism was considered the most likely explanation for the enrichment. Where enrichments were constant prior to the 20th century but increased greatly in the 20th century, the increased enrichment was attributed to anthropogenic activity. Table 3 shows the average enrichments of some of the measured elements beyond those concentrations expected from rock dust and sea salt, as well as average enrichments corresponding to the periods $6500 \mathrm{BP}-\mathrm{AD} 1884$ and AD 1898-1989. Using Pb isotopes, Vallelonga and others (2002b) observed that anthropogenic Pb inputs to Law Dome became observable from approximately AD 1890 while inputs of other anthropogenically emitted heavy metals such as $\mathrm{Cd}, \mathrm{Cu}$ and $\mathrm{Zn}$ were identified in Coats Land snow deposited during the 20th century (Wolff and others, 1999; Planchon and others, 2002).

Based on concentration enrichments above levels corresponding to inputs of rock dust and sea salt, the data presented here suggest that volcanism is an important source of the $\mathrm{Bi}, \mathrm{Cd}, \mathrm{Co}, \mathrm{Cu}, \mathrm{Pb}$ and $\mathrm{Zn}$ deposited at Law Dome. 
Table 3. Average enrichments of elements measured in Law Dome ice over various time periods. Enrichments are defined as the ratio of concentration beyond that expected from observed rock-dust and sea-salt concentrations

\begin{tabular}{|c|c|c|c|c|c|c|c|c|c|c|}
\hline Time period & V & $U$ & $\mathrm{~Pb}$ & $\mathrm{Cd}$ & $\mathrm{Sr}$ & $\mathrm{Bi}$ & $\mathrm{Co}$ & $\mathrm{Cu}$ & $\mathrm{Mn}$ & $\mathrm{Zn}$ \\
\hline 6500 BP-AD 1989 (all data) & 3.9 & 3.7 & 22 & 249 & 1.4 & 148 & 36 & 22 & 3.1 & 16 \\
\hline AD 1898-1989 (20th century) & 2.3 & 2.7 & 31 & 269 & 1.5 & 90 & 18 & 31 & 2.6 & 27 \\
\hline
\end{tabular}

The magnitudes of the average enrichments calculated vary from moderate values for $\mathrm{Zn}$ (16), $\mathrm{Pb}$ and $\mathrm{Cu}$ (22) and Co (36) to greater values for $\mathrm{Bi}$ (148) and Cd (249), as shown in Table 3. The origin of these concentration enrichments can be attributed to volcanic activity because they are constant through the duration of the data presented: from the mid-Holocene, $6500 \mathrm{BP}$, to the present, $\mathrm{AD} 1989$. These results are in agreement with previous reports that have suggested that Bi (Rosman and others, 1998) and $\mathrm{Cd}$ and $\mathrm{Pb}$ (Matsumoto and Hinkley, 2001) deposited in Antarctica originate predominantly from volcanogenic aerosols.

These data support previous findings that anthropogenic emissions have produced increased concentrations of $\mathrm{Pb}$, and possibly $\mathrm{Cu}$, in Antarctica. This finding was based on the increase of enrichments (beyond what could be accounted for by rock-dust and sea-salt inputs) of $\mathrm{Pb}$ and $\mathrm{Cu}$ observed during the 20th century compared to average enrichments for earlier centuries. For $\mathrm{Pb}$, the enrichment is observed to increase from 13 to 31 (as shown in Table 3) after AD 1898. For $\mathrm{Cu}$, a smaller increase in enrichment is observed, from 21 in the pre-industrial period (6500 BP-AD 1884) to 31 during the 20th century. Such an increase suggests only a minor contribution from anthropogenic $\mathrm{Cu}$ emissions, but this is consistent with the findings of Wolff and others (1999), who attributed increased concentrations of $\mathrm{Cu}$ in Coats Land snow deposited during the 1970s and 1980s to anthropogenic emissions.

Of the heavy metals studied here, $\mathrm{Zn}$ has the most spurious trend, with no indication that the element has been clearly enriched by anthropogenic emissions. This is due to contamination problems: the majority of data obtained from the most recent part of the ice-core record were negated by contamination. Of the samples corresponding to the period 1964-89, the lowest $\mathrm{Zn}$ concentration measured was $15 \mathrm{pg} \mathrm{g}^{-1}$, which is given here as an upper limit and is included only to delineate a possible $\mathrm{Zn}$ concentration trend for the late 20th century. This one sample is responsible for the high value (27) in Table 3 reported for the average enrichment of $\mathrm{Zn}$ above concentrations expected from rock dust and sea salt at all times for the period AD 1890-1989. If this potentially contaminated data point had not been included in the average, the calculated enrichment would be 11 , identical to that calculated for the period prior to AD 1890, indicating that anthropogenic emissions of $\mathrm{Zn}$ during the 20th century cannot be evaluated from the data presented. Wolff and others (1999) also failed to identify a trend for $\mathrm{Zn}$, from their analysis of $\mathrm{Cd}, \mathrm{Cu}$ and $\mathrm{Zn}$ in Coats Land snow corresponding to the period AD 1923-86.

\section{DISCUSSION}

The data presented here allow an evaluation of the main natural emission sources of each of the elements analyzed as well as an estimate of the proportions in which they are deposited in Law Dome snow. Reliable proxies of crustal aerosol (rock dust: $\mathrm{Ba}$ ) and marine aerosol (sea salt: $\mathrm{Ca}$ and $\mathrm{Na}$ ) emission were selected in order to independently calculate total concentrations of rock dust and sea salts present in the samples. Using reported elemental compositions of crustal material and sea water, the crustal and marine inputs from each of these sources were calculated for each sample. Where the concentrations of an element in the sample exceeded the concentration calculated from crustal and marine emissions, this remainder was attributed to inputs of volcanogenic or anthropogenic aerosols, depending on the age of the sample. This method of interpretation has provided a means by which the influence of volcanogenic aerosols can be evaluated without requiring a proxy for volcanism, such as $\mathrm{S}$ or $\mathrm{Bi}$. Lead isotope analyses of these samples have been reported by Vallelonga and others (2002b), providing a reliable description of the influence of anthropogenic aerosol emissions and dust inputs at the Law Dome site.

Of the elements analyzed, it was determined that $\mathrm{Mn}, \mathrm{Sr}$, $\mathrm{U}$ and $\mathrm{V}$ predominantly originated from crustal and marine emissions, while $\mathrm{Bi}, \mathrm{Cd}, \mathrm{Co}, \mathrm{Cu}, \mathrm{Pb}$ and $\mathrm{Zn}$ originated predominantly from volcanic aerosol emissions. Concentrations of $\mathrm{Mg}, \mathrm{Sr}, \mathrm{U}$ and $\mathrm{V}$ were only minimally enriched above levels accountable by inputs of rock dust and sea salt, indicating that volcanism was not a major emission source for these elements. It was determined that crustal sources accounted for the majority of $\mathrm{Mn}, \mathrm{U}$ and $\mathrm{V}$ while $\mathrm{Sr}$ predominantly originated from sea salts. Of these elements, pre-industrial (6500 BP-AD 1884) enrichments of $U$ and $V$ were 4.7 and 5.5, respectively, suggesting a possible minor volcanic influence for these elements. In comparison, average concentrations of $\mathrm{Bi}, \mathrm{Cd}, \mathrm{Co}, \mathrm{Cu}, \mathrm{Pb}$ and $\mathrm{Zn}$ were enriched at least one order of magnitude greater than those concentrations expected from rock-dust and sea-salt inputs, providing a strong indication that these elements predominantly originated from volcanic emissions. Average enrichments of $\mathrm{Bi}$ and $\mathrm{Cd}$ were 148 and 249, respectively, indicating that volcanism was likely to be the overwhelming emission source of these two elements, while average enrichments of $\mathrm{Co}, \mathrm{Cu}, \mathrm{Pb}$ and $\mathrm{Zn}$ were within the range 16-36, indicating that the Earth's crust and/or oceans are still important emission sources for these elements.

Ratios of 'excess' $\mathrm{Pb} / \mathrm{Bi}$ and $\mathrm{Pb} / \mathrm{Cd}$, attributed to volcanism, were compared to the most recent compilation of elemental abundances in volcanic emissions and found to be similar in the case of $\mathrm{Pb} / \mathrm{Cd}$. The 'excess' concentration of an element was defined as the remainder after the concentration of that element originating from inputs of rock dusts and sea salt had been subtracted from the concentration measured in the sample. It was found that the proportions of 'excess' $\mathrm{Bi}, \mathrm{Cd}$ and $\mathrm{Pb}$ were different during the 20th century than in earlier centuries, so only the samples corresponding 
to natural aerosol inputs, between $6500 \mathrm{BP}$ and AD 1884, were considered in this calculation. 'Excess' concentrations of $\mathrm{Bi}, \mathrm{Cd}$ and $\mathrm{Pb}$ were then compared to see if they accurately reflected the ratios that might be expected if they had been emitted from a volcano. In their compilation of available data, Hinkley and others (1999) reported that the average ratios of $\mathrm{Pb} / \mathrm{Bi}$ and $\mathrm{Pb} / \mathrm{Cd}$ for volcanic emissions were $1 / 0.47$ and $1 / 0.32$, respectively. By comparison, it has been found here that ratios of 'excess' $\mathrm{Pb} / \mathrm{Bi}$ and $\mathrm{Pb} / \mathrm{Cd}$ in Law Dome ice corresponding to the period 6500 BP-AD 1884 were $1 / 0.14$ and $1 / 0.41$, respectively. These results are in agreement with the ratios reported for volcanic emissions in the case of $\mathrm{Cd}$, but for $\mathrm{Bi}$ there is greater discrepancy, suggesting that $\mathrm{Bi}$ may be fractionated from $\mathrm{Pb}$ during atmospheric transport.

\section{CONCLUSIONS}

Using high-resolution ICP-SFMS, several major, minor and trace elements were measured in ice- and firn-core samples from Law Dome and used to evaluate inputs from natural aerosol emission sources such as crustal rock and soil dust, sea salts and volcanism. It was found that volcanism is a major source of heavy metals deposited at Law Dome and is likely the major natural emission source of aerosols containing $\mathrm{Bi}, \mathrm{Cd}, \mathrm{Co}, \mathrm{Cu}, \mathrm{Pb}$ and $\mathrm{Zn}$. Ratios of concentrations of other elements, including $\mathrm{Mn}, \mathrm{Sr}, \mathrm{U}$ and $\mathrm{V}$, were generally accountable as a combination of inputs derived from crustal and marine aerosol sources. Concentrations of $\mathrm{Bi}, \mathrm{Cd}$ and $\mathrm{Pb}$ apportioned to volcanic aerosols were calculated and compared to those reported for volcanic emissions and were found to be in good agreement for $\mathrm{Pb}$ and $\mathrm{Cd}$. Several $\mathrm{Zn}$ samples, particularly those corresponding to the second half of the 20th century, were contaminated, so no clear trend of anthropogenic influence could be observed for this metal.

\section{REFERENCES}

Barbante, C. and 7 others. 2003. Seasonal variations of heavy metals in central Greenland snow deposited from 1991 to 1995. J. Environ. Monitor., 5(2), 328-335.

Basile, I., F. E. Grousset, M. Revel, J. R. Petit, P. E. Biscaye and N. I. Barkov. 1997. Patagonian origin of glacial dust deposited in East Antarctica (Vostok and Dome C) during glacial stages 2, 4 and 6. Earth Planet. Sci. Lett., 146(3-4), 573-589.

Boutron, C. F., C. C. Patterson, V. N. Petrov and N. I. Barkov. 1987. Preliminary data on changes in lead concentrations in Antarctic ice from 155,000 to 26,000 years B.P. Atmos. Environ., 21(5), 1197-1202.

Bowen, H.J.M. 1979. Environmental chemistry of the elements. London, Academic Press.

Candelone, J. P., S. M. Hong and C. F. Boutron. 1994. An improved method for decontaminating polar snow or ice cores for heavy metal analysis. Anal. Chim. Acta, 299(1), 9-16.

Curran, M. A. J., T. D. van Ommen and V. Morgan. 1998. Seasonal characteristics of the major ions in the high-accumulation Dome Summit South ice core, Law Dome, Antarctica. Ann. Glaciol., 27, 385-390.

Dick, A.L. 1991. Concentrations and sources of metals in the Antarctic Peninsula aerosol. Geochim. Cosmochim. Acta, 55(7), 1827-1836.

Duce, R. A., G. L. Hoffman and W. H. Zoller. 1975. Atmospheric trace metals at remote Northern and Southern Hemisphere sites: pollution or natural? Science, 187(4171), 59-61.

Hinkley, T.K., P.J. Lamothe, S.A. Wilson, D. L. Finnegan and T.M. Gerlach. 1999. Metal emissions from Kilauea, and a suggested revision of the estimated worldwide metal output by quiescent degassing of volcanoes. Earth Planet. Sci. Lett., 170(3), 315-325.

Hong, S., C. F. Boutron, R. Edwards and V. I. Morgan. 1998. Heavy metals in Antarctic ice from Law Dome: initial results. Environ. Res., 78(2), 94-103.

Matsumoto, A. and T. Hinkley. 2001. Trace metal suites in Antarctic pre-industrial ice are consistent with emissions from quiescent degassing of volcanoes worldwide. Earth Planet. Sci. Lett., 186(1), 33-43.

Morgan, V.I., C. W. Wookey, J. Li, T. D. van Ommen, W. Skinner and M. F. Fitzpatrick. 1997. Site information and initial results from deep ice drilling on Law Dome, Antarctica. J. Glaciol., 43(143), 3-10.

Nriagu, J.O. 1989. A global assessment of natural sources of atmospheric trace metals. Nature, 338(6210), 47-49.

Palmer, A.S., T.D. van Ommen, M.A. J. Curran, V.I. Morgan, J. M. Souney and P. A. Mayewski. 2001. High precision dating of volcanic events (AD 1301-1995) using ice cores from Law Dome, Antarctica. J. Geophys. Res., 106(D22), 28,089-28,096.

Petit, J.-R. and 18 others. 1999. Climate and atmospheric history of the past 420,000 years from the Vostok ice core, Antarctica. Nature, 399(6735), 429-436.

Planchon, F. A. M. and 7 others. 2001. Ultrasensitive determination of heavy metals at the sub-picogram per gram level in ultraclean Antarctic snow samples by inductively coupled plasma sector field mass spectrometry. Anal. Chim. Acta, 450(1-2), 193-205.

Planchon, F. A. M. and 7 others. 2002. Changes in heavy metals in Antarctic snow from Coats Land since the mid-19th to the late20th century. Earth Planet. Sci. Lett., 200(1-2), 207-222.

Planchon, F. A. M., K. Van de Velde, K. J. R. Rosman, E. W. Wolff, C.P. Ferrari and C.F. Boutron. 2003. One hundred fifty-year record of lead isotopes in Antarctic snow from Coats Land. Geochim. Cosmochim. Acta, 67(4), 693-708.

Rosman, K. J. R., W. Chisholm, C. F. Boutron, J.-P. Candelone and C. C. Patterson. 1994a. Anthropogenic lead isotopes in Antarctica. Geophys. Res. Lett., 21(24), 2669-2672.

Rosman, K. J.R., W. Chisholm, C. F. Boutron, J.-P. Candelone and S. Hong. 1994b. Isotopic evidence to account for changes in the concentration of lead in Greenland snow between 1960 and 1988. Geochim. Cosmochim. Acta, 58(15), 3265-3269.

Rosman, K.J.R., W. Chisholm, S. Hong, J.-P. Candelone and C. F. Boutron. 1997. Lead from Carthaginian and Roman Spanish mines isotopically identified in Greenland ice dated from 600 B.C. to 300 A.D. Environ. Sci. Technol., 31(12), 3413-3416.

Rosman, K.J.R. and 6 others. 1998. Lead isotopes and selected metals in ice from Law Dome, Antarctica. Ann. Glaciol., 27, 349-354.

Taylor, S. R. and S. M. McLennan. 1985. The continental crust: its composition and evolution. Oxford, Blackwell Scientific Publications.

Vallelonga, P., K. van de Velde, J.-P. Candelone, V.I. Morgan, C. F. Boutron and K.J.R. Rosman. 2002a. The lead pollution history of Law Dome, Antarctica, from isotopic measurements on ice cores: 1500 AD to 1989 AD. Earth Planet. Sci. Lett., 204(1-2), 291-306.

Vallelonga, P. and 7 others. 2002b. Recent advances in the measurement of $\mathrm{Pb}$ isotopes in polar ice and snow at subpicogram per gram concentration using thermal ionisation mass spectrometry. Anal. Chim. Acta, 453(1), 1-12.

Vallelonga, P., J.-P. Candelone, K. van de Velde, M. A. J. Curran, V.I. Morgan and K.J.R. Rosman. 2003. Lead, Ba and Bi in Antarctic Law Dome ice corresponding to the 1815 AD Tambora eruption: an assessment of emission sources using $\mathrm{Pb}$ isotopes. Earth Planet. Sci. Lett., 211(3-4), 327-339.

Weisel, C. P., R. A. Duce, J. L. Fasching and R. W. Heaton. 1984. Estimates of the transport of trace metals from the ocean to the atmosphere. J. Geophys. Res., 89(D7), 11,607-11,618.

Wolff, E.W., E.D. Suttie and D.A. Peel. 1999. Antarctic snow record of cadmium, copper, and zinc content during the twentieth century. Atmos. Environ., 33(10), 1535-1541. 